\title{
TINJAUAN YURIDIS TERHADAP PERJANJIAN YANG DILARANGDALAM UNDANG-UNDANG NDMDR 5 TAHUN 1999 TENTANG LARANGAN PRAKTEK MONDPDLI DAN PERSAINGAN USAHA TIDAK SEHATYANG DILAKUKAN OLEH PELAKU USAHA KERAMBA JARING APUNGDI HARANGGADLHDRISDN KABUPATEN SIMALLNGUN
}

\author{
Raida Nababan', Jeremia Saragih ${ }^{2}$ \\ Fakultas Hukum Universitas HKBP Nammensen, Medan \\ roidanababan @gmail.cam
}

\begin{abstract}
Info Artikel
Diterima : 08 September 2020

Revisi : 17 Oktober 2020

Terbit : 30 Desember 2020
\end{abstract}

\section{Key words:}

Prohibited Agreetments,

Monopolistic Pratices, Unfair

Business Competition.

\begin{abstract}
This study aims to analyze the forms of agreement prohibited in Law Number 5 of 1999 concerning the Prohibition of Monopolistic Practices and Unfair Business Competition carried out by floating net cage business actors in Haranggaol Horisan, Simalungun Regency. This study uses a juridical empirical and normative juridical approach, through field research and literature research to obtain primary data and secondary data. Literature study is carried out on statutory regulations and other literature and field research is carried out by interviewing business actars of floating net cages in Haranggaol Horison, Simalungun Regency. The data obtained were then analyzed using a quantitative approach and described by analytical descriptive. The results of the study concluded that the forms of agreements that are prohibited under Law 5 of 1999 carried out by business actors in Haranggaol Horison include oligopoly, price fixing agreements, oligapsony, and vertical integration. To prevent the form of a prahibited agreement, it is necessary to establish a cooperative for floating net cage fish business actars to supervise business competition, direct and mitigate the impact of unfair business competition.
\end{abstract}

Abstrak

Penelitian bertujuan untuk menganalisis bentuk perjanjian yang dilarang dalam Undang-undang Nomar 5 Tahun 1999 Tentang Larangan Praktek Monopoli Dan Persaingan Usaha Tidak Sehat yang dilakukan oleh pelaku usaha Keramba Jaring Apung di Haranggaol Horison Kabupaten Simalungun. Penelitian ini menggunakan pendekatan yuridis empiris dan yuridis normatif, melalui penelitian lapangan dan penelitian kepustakaan untuk memperaleh data primer dan data sekunder. Studi pustaka dilakukan pada peraturan perundang-undang maupun pustaka lainnya serta penelitian lapangan dilakukan dengan wawancara kepada pelaku usaha Keramba Jaring Apung di Haranggaol Horisan Kabupaten Simalungun. Data yang diperoleh kemudian dianalisis menggunakan pendekatan kuantitatif dan dijabarkan dengan deskriptif analitis. Hasil penelitian menyimpulkan bahwa bentuk-bentuk perjanjian yang dilarang berdasarkan Undang-Undang 5 Tahun 1999 yang dilakukan pelaku usaha di Haranggaol Horison antara lain oligopali, perjanjian penetapan harga, aligapsoni, dan integrasi vertikal. Untuk mencegah bentuk perjanjian yang dilarang perlu dibentuknya Koperasi bagi pelaku usaha ikan keramba jaring apung untuk mengawasi persaingan usaha, mengarahkan serta menanggulangi dampak dari persaingan usaha tidak sehat. 


\section{PENDAHULUAN}

Salah satu bentuk ekasistem perairan tawar adalah Danau, yang berfungsi sebagai penampung dan menyimpan air yang berasal dari air sungai, mata air maupun air hujan. Sebagai salah satu bentuk ekasistem air tawar, danau memegang peranan sangat penting dan potensial untuk dikembangkan dan di dayagunakan untuk berbagai kepentingan, seperti kepentingan ekonomi, perikanan, irigasi, sumber air bersih dan pariwisata. Sumber hayati perikanan ialah kemampuan dari pada suatu perairan untuk dimanfaatkan dalam usaha perikanan sehingga menghasilkan sejumlah tertentu berat basah berupa hasil perikanan yang ekonomis, penting, secara menguntungkan dan terus-menerus. Perikanan merupakan segala kegiatan yang bertujuan memanfaatkan sumber daya hayati perairan dan segalakegiatan yang bertujuan untuk memperlancar terlaksana kegiatan tersebut.'

Danau Toba merupakan sumber daya air yang mempunyai nilai sangat penting dan strategis, baik ditinjau dari fungsi ekologi, hidrologi, ekonomi maupun estetika. Hal ini berkaitan dengan manfaat Danau Toba sebagai habitat dari berbagai jenis organisme air, sebagai sumber air minum bagi masyarakat sekitarnya, sarana transportasi, sumber air pertanian, media perikanan (perikanan budidaya maupun perikaan tangkap), demikian juga halnya Haranggaol sebagai bagian dari wilayah Danau Toba. Di Haranggad, salah satu sumber ekonomi utama adalah Keramba Jaring Apung (KJA) yang diusahakan oleh keluarga-keluarga yang lazim disebut petani ikan. Dari aspek sacial ekononi, perkembangan budidaya ikan KJA (Keramba Jaring Apung) di perairan Danau Toba memberikan pengaruh yang positif bagi masyarakat khususnya masyarakat lokal, dimana kegiatan ini mampu meningkatkan pendapatan bagi masyarakat petani KJA. Selain itu, kehadiran budidaya ikan KJA juga mampu memperluas kesempatan kerja bagi masyarakat, sehinggat urut mengurangi angka pengangguran. Kegiatan budidaya ikan sistem KJA di Danau Toba ini telah dilakukan oleh masyarakat sejak tahun 19896, namun perkembangan KJA dengan pesat terjadi sejak tahun 1998 melalui budidaya jarring apung intensif berkepadatan ikan yang tinggi. ${ }^{2}$

Setiap aktivitas bisnis dapat terjadi persaingan (competition) di antara pelaku usaha. Persaingan dalam dunia usaha adalah cara yang efektif untuk mencapai pendayagunaan sumber daya secara optimal. Persaingan ini dapat berimplikasi pasitif dan juga dapat menjadi negatif jika dilakukan dengan perilaku negatif. ${ }^{3}$

Pesatnya perkembangan dunia usaha tanpa adanya suatu aturan yang tegas, dapat mengakibatkan timbulnya persaingan usaha tidak sehat bahkan juga dapat menimbulkan praktik manopoli oleh pelaku dalam dunia usaha tersebut. Persaingan usaha tidak sehat dapat dipahami sebagai kondisi persaingan di antara pelaku usaha yang berjalan secara unfair atau curang. Undang-Undang №. 5 Tahun 1999 tentang Larangan Praktik Monopoli dan Persaingan Usaha Tidak Sehat memberikan tiga indikator untuk menyatakan terjadinya persaingan usaha tidak sehat, yaitu: ${ }^{4}$

1. Persaingan usaha yang dilakukan secara tidak jujur

2. Persaingan usaha yang dilakukan dengan cara melawan hukum

\footnotetext{
${ }^{1}$ Karwapi. Perikanan di Indanesia. 1985 . (Jakarta: Jakarta Press)

2 Rismawati. Skripsi: Analisis Daya Dukung Perairan Danau Taba Terhadap Kegiatan Perikanan Sebagai Dasar Dalam Pengendalian Pencemaran Keramba Jaring Apung. 2010. (Medan: Universitas Sumatera Utara)

${ }^{3}$ Mustafa Kamal Rakan. Hukum Persaingan Usaha. 2010. (Jakarta: PT RajaGrafindo Persada). Hal. 1

${ }^{4}$ /bid. Hal. I0
}

Tinjauan Yuridis Terhadap Perjanjian Yang Dilarang dalam Undang-Undang Nomor 5 Tahun 1999 Entang Larangan Praktek Monopoli Dan Persaingan Usaha Tidak Sehat yang Dilakukan Dleh Pelaku Usaha Keramba Jaring Apung di Haranggaol horison Kabupaten Simalungun 
3. Persaingan usaha yang dilakukan dengan cara menghambat terjadinya persaingan diantara pelaku usaha.

Pada prinsipnya searang pelaku usaha bebas untuk menentukan sendiri pihak penjual atau pembeli atau pemasok suatu produk di pasar sesuai dengan berlakunya hukum pasar, oleh karena itu dilarang setiap perjanjian yang bertentangan dengan kebebasan tersebut dan dapat mengakibatkan timbulnya persaingan tidak sehat. $^{5}$

Sebagaimana yang terjadi dalam proses produksi ikan air tawar melalui Keramba Jaring Apung (KJA) di Haranggaol Horison. Terjadi banyak Pelaku usaha ikan yang melakukan perjanjian yang dilarang sebagaimana yang tercantum dalam Undang-undang nomor 5 Tahun 1999 tentang Larangan Praktek Monopoli dan Persaingan Usaha Tidak Sehat. Pelaku usaha (Tauke) melakukan penjatuhan harga pemasakan ikan dengan pelaku usaha lainnya (Pedagang). Selain itu terjadi persaingan usaha yang tidak sehat antara pelaku usaha yang lebih kuat (Tauke) dengan pelaku usaha yang lebih lemah (Petani ikan biasa). Kasus tersebut di atas bertentangan dengan ideolagi bangsa sebagaimana tercantum dalam sila kelima dalam pancasila yang menyatakan: "Keadilan sasial bagi seluruh rakyat Indanesia"Hal ini berkesinambungan dengan Pasal 33 Undang-undang dasar 1945 yang menyatakan:"Pereknnomian disusun sebagai usaha bersama berdasar atas asas kekeluargaan"ayat (I) dan "perekonomian nasional diselenggarakan berdasar atas demokrasi ekanomi dengan prinsip kebersamaan, efesiensi berkeadilan, berkelanjutan, berwawasan lingkungan, kemandirian, serta dengan menjaga keseimbangan kemajuan dan kesatuan ekonomi nasional"ayat (3).

Jika dilihat dari Undang-undang nomor 5 Tahun 1999 tentang Larangan Praktek Monopali dan Persaingan Usaha Tidak Sehat, kasus yang terjadi di Haranggaol Horison memenuhi unsur-unsur sebagaimana yang tercantum pada Pasal I6, 17 ayat (I), 17 ayat (2) b, dan pasal IS paint a, b, d, mengenai perjanjian yang

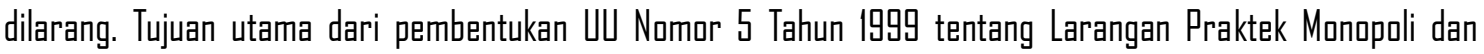
Persaingan Usaha tidak Sehat, yaitu: ${ }^{6}$

a. menjaga kepentingan umum dan meningkatkan efisiensi ekonami nasional sebagai salah satu upaya untuk meningkatkan kesejahteraan rakyat :

b. mewujudkan iklim usaha yang kondusif melalui pengaturan persaingan usaha yang sehat sehingga menjamin adanya kepastian kesempatan berusaha yang sama bagi pelaku usaha kecil ;

c. mencegah praktek monopoli dan atau persaingan usaha tidak sehat yang ditimbulkan oleh pelaku usaha ; dan

d. terciptanya efektivitas dan efisiensi dalam kegiatan usaha.

Sesuai ketentuan Undang-Undang Nomor 05 Tahun 1999 tentang Larangan Praktek Monopoli dan Persaingan Usaha tidak Sehat, bahwa yang merupakan perjanjian yang dilarang adalah: ${ }^{7}$

I. Perjanjian-perjanjian tertentu yang berdampak tidak baik untuk persaingan pasar, yang terdiri dari : (a) Cligapoli; (b) Penetapan harga; (c) Pembagian wilayah; (d) Pembaikatan; (d) Kartel; (e) Trust; (f) Dligapsani; (g) Integrasi vertical; (h) Perjanjian tertutup; dan (i) Perjanjian dengan pihak luar negeri.

\footnotetext{
5 Ibid. Hal. 124

${ }^{6}$ Undang-UndangNomor 5 Tahun 1999 tentang Larangan Praktek Monopoli dan Persaingan Lsaha Tidak Sehat, Pasal 3

${ }^{7}$ Akumulasi Ketentuan UU No. 5/1999 dan Chatamarrasjid, Uل Larangan Praktik Monopoli (Magna Charta Bagi Kebebasan Berusaha), Jurnal hukum Bisnis, Vol. 7, Yayasan Pengembangan Hukum Bisnis, 1999. Hal.43.
}

Tinjauan Yuridis Terhadap Perjanjian Yang Dilarang dalam Undang-Undang Nomor 5 Tahun 1999 T 
2. Kegiatan-kegiatan tertentu yang berdampak tidak baik untuk persaingan pasar, yang meliputi kegiatan-kegiatan sebagai berikut : (a) Monopoli; (b) Monopsoni; (c) Penguasaan pasar; (d) Persekongkolan; dan (e) Posisi dominan, yang meliputi :

a. Pencegahan konsumen untuk memperoleh barang atau jasa yang bersaing:

b. Pembatasan pasar dan pengembangan teknologi;

c. Menghambat pesaing untuk bisa masuk pasar;

d. Jabatan rangkap;

e. Pemilikan saham; dan

f. Merger, akuisisi, knnsolidasi.

Mengenai perjanjian yang dilarang dalam Undang-Undang No. 5 Tahun 1999 Tentang Larangan Praktek Monopoli Dan Persaingan Usaha Tidak Sehat, jelaslah sebagai pengaturan sejumlah perjanjian yang tidak boleh dibuat dan dilakukan oleh para pelaku usaha. Menurut Ahmadi Miru, ${ }^{8}$ sejumlah perjanjian sebagai perjanjian yang diatur secara khusus yang mendampingi perjanjian menurut KUHPerdata yang mengatur ruang lingkupnya secara khusus, antara lain adalah:Perjanjian antara pelaku usaha dan pelaku usaha secara khusus yang diatur dalam Undang-Undang No. 5 Tahun 1999 tentang Larangan Praktik Manopali dan Persaingan Usaha Tidak Sehat.

a. Perjanjian antara pelaku usaha dan konsumen, yang diatur di dalam Undang- Undang No. 8 Tahun 1999 tentang Perlindungan Konsumen.

b. Perjanjian antara nomprofessional dan nomprofessional lainnya yang diatur dalam peraturan perundangan tersendiri.

Undang-Undang №. 5 Tahun 1999Tentang Larangan Praktek Monopali Dan Persaingan Usaha Tidak Sehat menurut perjanjian yang dilarang pada Bab III, yang terdiri atas: Cligopoli; Penetapan harga; Pembagian wilayah; Pemboikotan; Kartel; Trust; Cligopsani; Integrasi vertikal; Perjanjian tertutup; danPerjanjian dengan pihak luar negeri. Diundangkannya لال №. 5 tahun 1999 bertujuan untuk mencegah timbulnya praktik monopoli dan/atau persaingan usaha tidak sehat salah satunya yaitu mengenai perjanjian yang dilarang dalam bentuk Monopoli maupun dalam bentuk Penguasaan pasar. Dalam Bab IV Undang-Undang No. 5 Tahun 1999 tentang Larangan Praktik Monopoli dan Persaingan Usaha Tidak Sehat terdapat salah satu bentuk perjanjian yang dilarang yaitu Monopoli dan Penguasaan pasar. Pada Pasal 17 Undang-Undang No. 5 Tahun 1999 tersebut menjelaskan Monopoli yang dilarang ialah sebagai berikut:Ayat (I):Pelaku usaha dilarang melakukan penguasaan atas produksi dan atau pemasaran barang dan atau jasa yang dapat mengakibatkan terjadinya praktek monopoli dan atau persaingan usaha tidak sehat.Ayat (2)b:Pelaku usaha patut diduga atau dianggap melakukan penguasaan atas produksi dan atau pemasaran barang dan atau jasa sebagaimana dimaksud dalam ayat (I) apabila mengakibatkan pelaku usaha lain tidak dapat masuk kedalam persaingan usaha barang dan atau jasa yang sama.

Tinjauan Umum tentang Perjanjian yang dilarang, bahwa Formasi perjanjian dalam Kitab UndangUndang Hukum Perdata pada pasal 1320 antara lain adalah:a. Adanya Kesepakatan Kehendak (Cansensus Agreement) $)^{9}$. Kesepakatan timbul karena adanya penawaran (affer) dan permintaan (acceptance). Penawaran tersebut akan berakhir jika jangka waktunya berakhir atau tidak disetujui pada waktu yang ditentukan. b.Suatu

\footnotetext{
${ }^{8}$ Dp Cit, Ahmadi Miru, Hal. I0-11

${ }^{9}$ Novina Sri Indiraharti, “Aspek Keabsahan Perjanjian dalam Hukum Kantrak', Hal. 21

Tinjauan Yuridis Terhadap Perjanjian Yang Dilarang dalam Undang-Undang Nomor 5 Tahun 1999 Entang Larangan Praktek Monopoli Dan Persaingan Usaha Tidak Sehat yang Dilakukan Dleh Pelaku Usaha Keramba Jaring Apung di Haranggaol horison Kabupaten Simalungun
} 
Hal Tertentu (Prestasi), prestasi dapat diartikan sebagai sesuatu yang dijanjikan, diberikan, atau dilakukan

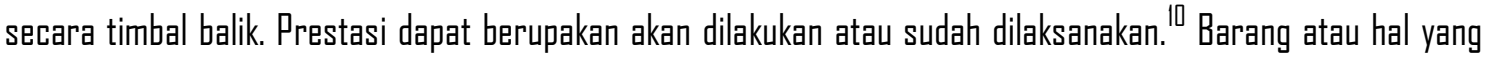
dimaksud dalam perjanjian paing sedikit dapat ditentukan jenisnya (determinable).c.Kausa yang Halal, menurut Pasal 1335 jo Pasal 1337 KLH Perdata menyatakan bahwa suatu kausa dinyatakan terlarang jika bertentangan dengan undang-undang, kesusilaan, dan ketertiban umum.Perjanjian yang Dilarang dalam Undang-Undang Nomor 5 Tahun 19, Pasal I313 KLH Perdata:"Perjanjian adalah suatu perbuatan dengan mana satu arang atau lebih mengikatkan dirinya terhadap satu arang lain atau lebih." Menurut Subekti, perjanjian ialah: "Suatu peristiwa dimana searang atau lebih berjanji kepada earang atau lebih lainnya untuk melaksanakan suatu hal." Dalam perkembangan sistem ekonomi Indonesia, persaingan usaha menjadi salah satu instrumen ekonomi sejak saat reformasi digulirkan. Hal ini ditunjukkan melalui terbitnya Undang-Undang Nomor 5 Tahun 1999 tentang Larangan Praktek Monopali dan Persaingan Usaha Tidak Sehat. ${ }^{12}$ Undang-undang Nomor 5 Tahun 1999 tentang Larangan Praktek Monopali dan Persaingan Usaha dibentuk dengan tujuan sebagaimana disebutkan pada Pasal 3, yaitu:

1. Menjaga kepentingan umum dan meningkatkan efisiensi ekanomi nasional sebagai salah satu upaya meningkatkan kesejahteraan rakyat;

2. Mewujudkan iklim usaha yang kondusif melalui pengaturan persaingan usaha yang sehat sehingga menjamin adanya kepastian kesempatan berusaha yang sama bagi pelaku usaha besar, pelaku usaha menengah dan pelaku usaha kecil;

3. Mencegah praktek monopoli dan persaingan usaha tidak sehat yang ditimbulkan oleh pelaku usaha;

4. Terciptanya efektifitas dan efisiensi dalam kegiatan usaha.

Oligopoli adalah monopoli oleh beberapa pelaku usaha "monapali by a view". Oligopoli dapat juga diartikan kondisi ekonomi dimana hanya ada beberapa perusahaan menjual barang yang sama atau produk yang standart, "ecanami candition where anly a view campany sell substantial similar ar standaried praduct". Uل № 5 Tahun 1999, Pasal 4 melarang perjanjian Dligopoli. "Pelaku usaha membuat perjanjian dengan pelaku usaha lainnya untuk secara bersama-sama melakukan penguasaan produksi atau pemasaran barang atau jasa yang dapat mengakibatkan terjadinya praktik monopali dan persaingan usaha tidak sehat. ${ }^{13}$ Bentuk pasar Oligopoli itu berada di antara Monopoli dan pasar persiangan sempurna (perfect campetition).

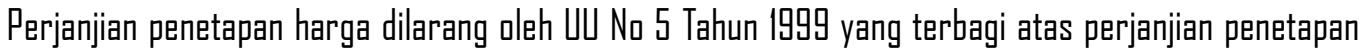
harga (Price Fixing Agreement) diatur dalam Pasal 5, diskrimanasi harga (Price Discrimination) diatur dalam Pasal 6, perjanjian jual rugi (Predatory Pricing) diatur dalam Pasal 7, dan pengaturan harga jual kembali (Resale Price Maintenance) diatur dalam Pasal 8.

Perjanjian Diskriminasi Harga dalam Undang-Undang Nomar 5 Tahun 199914. Pasal 6 U No. 5 Tahun 1999:15elaku usaha dilarang membuat perjanjian yang mengakibatkan pembeli yang satu harus membayar dengan harga yang berbeda dari harga yang harus dibayar oleh pembeli lain untuk barang dan/atau jasa yang sama.Ketentuan yang

\footnotetext{
${ }^{10}$ Abdul Kadir Muhammad, "HukumPerjanjiari", (Alumni; Bandung), 1988. Hal. 99

"Subekti, "Hukum Perjanjiari", Cetakan XVI, 1996. (Jakarta: Intermasa), Hal.I

${ }^{12}$ Konsiderans Undang-Undang Nomor 5 Tahun 1999 tentang Larangan Praktik Monopoli dan Persaingan Usaha TidakSehat.

${ }^{13}$ Undang-Undan Nomor 5 Tahun 1999 tentang Larangan Praktik Monopoli dan Persaingan Usaha Tidak Sehat, Pasal 4

${ }^{14} /$ bid, Hal. 338

${ }^{15}$ Undang-Undang Nomor 5 Tahun 1999 tentang Larangan Praktik Monopoli dan Persainan Usaha Tidak Sehat, Pasal G
}

Tinjauan Yuridis Terhadap Perjanjian Yang Dilarang dalam Undang-Undang Nomor 5 Tahun 1999 T

Entang Larangan Praktek Monopoli Dan Persaingan Usaha Tidak Sehat yang Dilakukan Dleh Pelaku

Usaha Keramba Jaring Apung di Haranggaol horison Kabupaten Simalungun 
mengatur mengenai diskriminasi harga ini, diatur secara $P E r$ Se, sehingga berakibat pelaku usaha yang melakukan perbuatan yang dilarang oleh Pasal 6 tersebut dapat dijatuhi sanksi hukum oleh penegak hukum tanpa terlebih dahulu melihat bahwa yang dilakukan tersebut menimbulkan akibat tertentu atau tidak.

1. Jual Rugi (Predatory Pricing) ${ }^{16}$ adalah salah satu bentuk strategi yang dilakukan oleh pelaku usahadalam menjual produk dengan harga yang sangat rendah, yang tujuan utamanya untuk menyingkirkan pelaku usaha pesaing dari pasar dan juga mencegah pelaku usaha yang berpotensi menjadi pesaing untuk masuk ke dalam pasar yang sama, segera setelah berhasil mengusir pelaku usaha pesaing dan menunda masuknya pelaku usaha pendatang baru, selanjutnya dia dapat menaikkan harga kembali dan memaksimalkan keuntungan yang mungkin didapatkan.Jual Rugi dalam Undang-Undang Nomor 5 Tahun 1999, Pasal 7 Undang-undang No.5/1999 dihubungkan dengan ketentuan yang ada pada Pasal 20 Undang-undang No.5/1999 adalah Pasal 7 mengatur mengenai predatary pricing yang didasarkan kepada perjanjian sedangkan Pasal 20 mengatur mengenai predatory pricing yang didasarkan kepada tindakan sepihak dari pelaku usaha.

2. Penetapan Harga Jual Kembali (Resa/e Price Maintance) ${ }^{17}$ adalah adanya perjanjian di antara pelaku usaha, umumnya perusahaan manufaktur dengan para perusahaan penyalurnya, yang memuat persyaratan bahwa penerima barang dan/atau jasa tidak akan menjual atau memasok kembali barang dan atau jasa yang diterimanya, dengan harga yang lebih rendah daripada harga yang diperjanjikan (resale price maintenance), sehingga membuat persaingan di tingkat perusahaan penyalur menjadi hilang.Penetapan Harga Jual Kembali dalam Undang-Undang Namar 5 Tahun 1999, Pasal 8 menyatakan bahwa: ${ }^{18}$ pelaku usaha dilarang membuat perjanjian dengan pelaku usaha lain yang memuat persyaratan bahwa penerima barang dan/atau jasa tidak akan menjual atau memasok kembali barang dan/atau jasa yang diterimanya, dengan harga yang lebih rendah daripada harga yang telah diperjanjikan sehingga dapat mengakibatkan terjadinya persaingan usaha tidak sehat."

1. Perjanjian Pembagian Wilayah Pemasaran, ${ }^{19}$ dalam Undang-Undang Nomar 5 Tahun 199920 Pasal 9 yang berbunyi:pelaku usaha dilarang membuat perjanjian dengan pelaku usaha pesaingnya yang bertujuan untuk membagi wilayah pemasaran atau alokasi pasar terhadap barang dan/atau jasa sehingga dapat mengakibatkan terjadinya praktek monopoli dan persaingan usaha tidak sehat." Ketentuan yang mengatur mengenai perjanjian pembagian wilayah oleh oleh Undang-undang No.5/1999 khususnya Pasal 9 dirumuskan secara Rule of Reason, sehingga sebelum mengakibatkan terjadinya praktik monopoli dan/atau persaingan usaha tidak sehat, pelaku usaha belum bisa dijatuhi hukuman berdasarkan pasal ini.

2. Perjanjian Pembaikatann ${ }^{21}$

a. Pengertian Perjanjian Baikot, adalah tindakan mengorganisasi suatu kelompok untuk menolak hubungan usaha dengan pihak tertentu atau tidak berhubungan dengan

\footnotetext{
${ }^{16}$ Dp.Cit, Abdulkadir Muhammad, Hal.. 339

${ }^{17}$ Ibid, Hal.. 342

${ }^{18}$ Undang-Undang Nomor 5 Tahun 1999 tentang Larangan Praktik Monopoli dan Persaingan Usaha Tidak Sehat, Pasal 8

${ }^{19} /$ bid, Hal. 344

${ }^{20} / \mathrm{bid}$, Hal. 345

${ }^{21}$ lbid, Hal. 362-364
}

Tinjauan Yuridis Terhadap Perjanjian Yang Dilarang dalam Undang-Undang Nomor 5 Tahun 1999 T Entang Larangan Praktek Monopoli Dan Persaingan Usaha Tidak Sehat yang Dilakukan Dleh Pelaku Usaha Keramba Jaring Apung di Haranggaol horison Kabupaten Simalungun 
pesaing-pesaing yang lain seperti kepada para supplier ataupun konsumen-kansumen tertentu.

b. Bentuk Perjanjian Baikat, ada dua macam perjanjian boikat yang dilarang oleh pasal ID, yaitu:

1. Perjanjian yang dapat menghalangi pelaku usaha lain (pihak ketiga) ntuk melakukan usaha yang sama

2. Perjanjian untuk menolak menjual setiap barang dan/atau jasa dari pelaku usaha lain (pihak ketiga), jika:

- Merugikan atau dapat diduga akan merugikan pelaku usaha lain tersebut

- Membatasi pelaku usaha lain dalam menjual atau membeli setiap barang dan/atau jasa dari pasar yang bersangkutan. ${ }^{22}$

c. Perjanjian Baikot dalam Undang-Undang Nomor 5 Tahun 1999, sebagai salah satu perjanjian yang dilarang, dimana di atur di dalam Pasal 10 ayat (I) dan (2) Undang-undang No.5/1999, Pasal I0 ayat (I) berbunyi: pelaku usaha dilarang membuat perjanjian, dengan pelaku usaha pesaingnya yang dapat menghalangi pelaku usaha lain untuk malakukan usaha yang sama, baik untuk tujuan pasar dalam negeri maupun pasar luar negeri. Dan Pasal ID ayat (2) nya, berbunyi: pelaku usaha dilarang membuat perjanjian dengan pelaku usaha pesaingnya, untuk menolak menjual setiap barang dan/atau jasa dari pelaku usaha lain sehingga perbuatan tersebut: (a). Merugikan atau dapat diduga akan merugikan pelaku usaha lain: atau; (2) membatasi pelaku usaha lain dalam menjual atau membeli setiap barang dan/atau jasa dari pasar bersangkutan."

Perjanjian Kartel ${ }^{23}$ adalah Perjanjian satu produsen-produsen tertentu yang bertujuan untuk mengawasi produksi, penjualan, dan harga serta untuk melakukan monopali terhadap kamaditas atau industry tertentu. ${ }^{24}$

a. Bentuk Perjanjian Kartel, merupakan salah satu strategi yang diterapkan diantara pelaku usaha untuk dapat mempengaruhi harga dengan mengatur jumlah praduksi mereka. Mereka berasumsi jika produksi mereka di dalam pasar dikurangi sedangkan permintaan terhadap produk mereka di dalam pasar tetap, akan berakibat kepada terkereknya harga ke tingkat yang lebih tinggi. Dan sebaliknya, jika di dalam pasar produk mereka melimpah, sudah barang tentu akan berdampak terhadap penurunan harga produk mereka di pasar.Kartel dalam Undang-Undang Nomor 5 Tahun 1999, Pasal II Undang-undang №.5/1999 berbunyi: "pelaku usaha dilarang membuat perjanjian, dengan pelaku usaha pesaingnya yang bermaksud untuk mempengaruhi harga dengan cara mengatur produksi dan/atau pemasaran suatu barang dan/atau jasa, yang dapat mengakibatkan terjadinya praktek monopoli dan persaingan usaha tidak sehat.Perumusan kartel secara Rule of Reasun oleh pembentuk undang-undang No.5/1999 dapat diartikan pelaku usaha dapat membuat perjanjian dengan pelaku usaha pesaingnya yang bermaksud untuk mempengaruhi harga dengan mengatur produksi atau pemasaran suatu barang atau jasa asalkan tidak mengakibatkan terjadinya praktek monopoli dan persaingan usaha tidak sehat.

Perjanjian Trust,

Menurut R.B. Suhartono, trust merupakan wadah antar perusahaan yang di desain untuk membatasi persaingan dalam bidang usaha atau industri tertentu. Gabungan antara beberapa perusahaan dalam bentuk

\footnotetext{
${ }^{22}$ Susanti Adi Nugroho, "Pengaturan Hukum Persaingan Usaha di Indonesia", 2001. (Jakarta: Puslitbang/Diklat Mahkamah Agung), Hal. 40 ${ }^{23} /$ bid, Hal. 364-366

${ }^{24}$ Henry Campbell Black, Black Law Dictianary, 1999, (St Paul West Publishing Co.,), Hal. 215
} 
trust dimaksudkan untuk secara kolektif mengendalikan pasakan, dengan melibatkan trustee sebagai koordinatar penentu harga. Dengan menempatkan saham-saham dari berbagai badan usaha dalam suatu trust maka dapat di jamin tidak hanya kesatuan langkah kolektif tetapi juga pembagian keuntungan bersama yang lebih besar dibandingkan tiadanya trust. ${ }^{25}$

a. Bentuk Perjanjian Trust, di Indanesia untuk sekarang ini, Trust belum dapat ditemui dalam praktek keseharian, sehingga beberapa kalangan berpendapat alangkah lebih baik jika hal yang di atur dalam Pasal 12 ini direvisi saja, untuk menyesuaikan dengan keadaan yang terjadi di Indanesia dan lagi ketentuan yang di atur oleh Pasal I2 ini bisa dicaver dengan pasal lainnya.

b. Perjanjian Trust dalam Undang-Undang Nomar 5 Tahun 1999, Pasal I2 Undang -undang No.5/1999 yang berbunyi: pelaku usaha dilarang membuat perjanjian dengan membentuk gabungan perusahaan atau perseroan yang lebih besar, dengan tetap menjaga dan mempertahankan kelangsungan hidup masing-masing perusahaan atau perseroan anggotanya yang bertujuan untuk mengantrol produksi dan/atau pemasaran atas barang dan/atau jasa, sehingga dapat mengakibatkan terjadinya praktik monopoli dan/atau persaingan usaha tidak sehat."

Perjanjian Dligapsani

Oligopsoni adalah struktur pasar yang di dominasi oleh sejumlah konsumen yang memiliki kontrol atas pembelian. Struktur pasar ini memiliki kesamaan dengan struktur pasar oligopoli hanya saja struktur pasar ini terpusat di pasar input. Dengan demikian distarsi yang ditimbulkan oleh kolusi antar pelaku pasar akan mendistorsi pasar input.Perjanjian Dligopsani dalam Undang-Undang Nomor 5 Tahun 1999, Pasal 13 ayat (I) Undang-undang №.5/1999 menyebutkan bahwa: pelaku usaha dilarang membuat perjanjian dengan pelaku usaha lain yang bertujuan untuk secara bersama-sama menguasai pembelian atau penerimaan pasakan agar dapat mengendalikan harga atas barang dan/atau jasa dalam pasar bersangkutan, yang dapat mengakibatkan terjadinya praktek monopoli dan/atau persaingan usaha tidak sehat. Sedangkan Pasal 13 ayat (2) menambahkan bahwa: pelaku usaha patut diduga atau dianggap secara bersama-sama menguasai pembelian atau penerimaan pasakan sebagaimana dimaksud dalam ayat (I) apabila 2 (dua) atau 3 (tiga) pelaku usaha atau kelompok pelaku usaha menguasai lebih dari 75\% (tujuh puluh lima persen) pangsa pasar satu jenis barang atau jasa tertentu.

Perjanjian Integrasi Vertikal,adalah segala praktik yang bertujuan untuk mencapai suatu kondisi yang membatasi persaingan dalam dimensi vertikal atau dalam perbedaan jenjang produksi atau dalam usaha yang memiliki keterkaitan sebagai rangkaian produksi atau rangkaian usaha.Perjanjian Integrasi Vertikal dalam UndangUndang Namor 5 Tahun 1999, Pasal 14 Undang-undang No.5/1999 menyebutkan bahwa: pelaku usaha dilarang membuat perjanjian dengan pelaku usaha lain yang bertujuan untuk menguasai produksi sejumlah produk yang termasuk dalam rangkaian produksi barang dan/atau jasa tertentu yang mana setiap rangkaian produksi merupakan hasil pengolahan atau proses lanjutan, baik dalam satu rangkaian langsung maupun tidak langsung, yang dapat mengakibatkan terjadinya persaingan usaha tidak sehat dan/atau merugikan masyarakat."

Perjanjian Tertutup (Exc/usive agreement), merupakan perjanjian antara pelaku usaha selaku pembeli dan penjual untuk melakukan kesepakatan secara eksklusif yang dapat berakibat menghalangi dan menghambat

${ }^{25}$ R.B. Suhartono, Konglomerasi dan Relavansi Uل Antitrust/ Uل Antimonopoli dilndonesia,Jurnal Hukum Bisnis, Volume 4tahun 1998, Hal.6. 
pelaku usaha lain untuk melakukan kesepakatan yang sama, salah satunya dengan penetapan harga. ${ }^{26}$ Tying Agreement,merupakan salah satu kategori perjanjian yang dilarang menurutUndang-undang №.5/1999, karena dengan praktek tying agreement, pelaku usaha dapat melakukan perluasan kekuatan monopoli yang dimiliki pada tying Praduct (barang atau jasa yang pertama kali dijual) ke tyied product (barang atau jasa yang dipaksa harus dibeli juga oleh konsumen). Sebagai contoh, Indafoad memiliki kekuatan manopali untuk produk mie instant, tetapi dia ingin memanfaatkan kekuatan monopolinya tersebut agar dapat memiliki kekuatan monopoli untuk produk lain.

Vertical agreement an Discount, jika pelaku usaha ingin mendapatkan harga diskan untuk produk tertentu yang dibelinya dari pelaku usaha lain, pelaku usaha harus bersedia membeli produk lain dari pelaku usaha tersebut atau tidak akan membeli produk yang sama atau sejenis dari pelaku usaha lain yang menjadi pesaing.Perjanjian Tertutup dalam Undang-Undang Nomor 5 Tahun 1999, Pasal 15 ayat (I) Undang-undang No.5/1999 sebagai berikut, bahwa: Pelaku usaha dilarang membuat perjanjian dengan pelaku usaha lain yang memuat persyaratan bahwa pihak yang menerima barang dan/atau jasa hanya akan memasak atau tidak memasak kembali barang dan/atau jasa tersebut kepada pihak tertentu dan/atau pada tempat tertentu. Pasal 15 ayat (2) Undang-undang No.5/1999 menyatakan bahwa: pelaku usaha dilarang membuat perjanjian dengan pihak lain yang memuat persyaratan bahwa pihak yang menerima barang dan/atau jasa tertentu harus bersedia membeli barang dan/atau jasa lain dari pelaku usaha pemasak.Pasal l5 ayat (3) Undang-undang No.5/1999 menyatakan bahwa: pelaku usaha dilarang membuat perjanjian mengenai harga atau potongan harga tertentu atas barang dan/atau jasa yang memuat persyaratan bahwa pelaku usaha yang menerima barang dan/atau jasa dari usaha pemasok:

a. harus bersedia membeli barang dan/atau jasa lain dari pelaku usaha pemasok; atau

b. tidak akan membeli barang dan/atau jasa yang sama atau sejenis dari pelaku usaha lain yang menjadi pesaing dari pelaku usaha pemasak."

Perjanjian dengan Pihak Luar Negeri, Perjanjian dengan luar negeri adalah perjanjian yang dapat merusak persaingan usaha dan melakukan tindak monopoli.Perjanjian dengan Pihak Luar Negeri dalam UndangUndang Nomor 5 Tahun 1999, Pasal I6 Uل No.5/1999 menyebutkan bahwa: pelaku usaha dilarang membuat perjanjian dengan pihak lain di luar negeri yang memuat ketentuan yang dapat mengakibatkan terjadinya praktik monopoli dan/atau persaingan usaha tidak sehat.

Pelaku Usaha, Pasal I angka 5 Undang-undang Nomar 5 Tahun 1999 definisi Pelaku usaha adalah:setiap orang perorangan atau badan usaha, baik yang berbentuk badan hukum atau bukan badan hukum yang didirikan dan berkedudukan atau melakukan kegiatan dalam wilayah hukum negara Republik Indanesia, baik sendiri maupun bersama-sama melalui perjanjiaan, menyelenggarakan berbagai kegiatan usaha dalam bidang ekonami."Dalam penjelasannya menyatakan bahwa pelaku usaha yang termaksud dalam pengertian ini adalah perusahaan, koperasi, BUMN, korporasi, importer, pedagang, distributor, danlain-lain.

Terdapat beberapa Prinsip-prinsip Pelaku Usaha ${ }^{27}$, antara lain:

\footnotetext{
${ }^{26}$ Mustafa Kamal Rakan, “Hukum Persaingan Usaha”, 2010, (Jakarta: Raja Grafindo Persada),Hal.17

${ }^{27}$ Noname, Pendekatan dan Prinsip Etika Bisnis Perusahaan, (https://www.jurnal.id/id/blag/pendekatan-dan-prinsip-etika-bisnisperusahaan/ diakses pada tanggal 22 Juni 2020)
} 
Prinsip Dtanami, mengharuskan pelaku bisnis mengambil keputusan dengan tepat dan baik, serta mempertanggung jawabkan keputusan tersebut. Dalam menjalankan prinsip otonomi ini, dua perusahaan atau lebih bisa berkamitmen menjalankan etika bisnis dengan prinsip otonami.

Prinsip Kejujuran, merupakan nilai yang paling dasar untuk mendukung keberhasilan kinerja perusahaan. Tanpa kejujuran, bisnis tidak akan bertahan lama, karena kejujuran adalah kunci utama dalam kesuksesan bisnis.

Prinsip Keadilan, dalam prinsip ini berarti setiap orang yang melakukan bisnis meiliki hak untuk mendapatkan perlakuan yang sama. Sehingga semua pihak yang terkait dalam bisnis harus memberikan kontribusi baik secara langsung atau tidak langsung terhadap keberhasilan bisnis.

Prinsip Layalitas, adalah salah satu hal penting dalam menjalankan sebuah bisnis. Loyalitas dalam perusahaan biasanya dapat dilihat dari kerja keras dan keseriusan dalam menjalani bisnis sesuai dengan visi dan misi.

Prinsip Integritas Moral, setiap perusahaan harus memiliki integritas moral yang baik. Dengan begitu, perusahaan lebih dapat dipercaya masyarakat. Menerapkan prinsip ini, berarti seluruh pelaku bisnis, baik karyawan hingga manajemen harus selalu menjaga nama baik perusahaan.Itulah beberapa pendekatan dan prinsip dalam menerapkan etika bisnis perusahaan. Dengan etika bisnis yang baik, perusahaan dapat berkembang dengan mudah.

Hak dan Kewajiban Pelaku Usaha, antara lain:Dari Pasal 4 Undang-Undang Perlindungan Konsumen, dapat disimpulkan bahwa pelaku usaha berkewajiban untuk menepati janji-janji serta memberikan segala infarmasi terkait barang dan/atau jasa.Pasal 7 huruf b UUPK menyatakan bahwa kewajiban pelaku usaha memberikan infarmasi yang benar, jelas dan jujur mengenai kondisi dan jaminan barang dan/atau jasa serta memberi penjelasan penggunaan, perbaikan dan pemeliharaan, dimana kewajiban dari pelaku usaha tersebut dapat dilihat juga sebagai hak dari konsumen.Sedangkan hak pelaku usaha adalah mendapatkan pembayaran atas barang dan/atau jasa sesuai dengan yang telah diperjanjikan.

Memperhatikan situasi dan kandisi tersebut, dituntut untuk mencermati dan menata kembali kegiatan usaha di Indanesia, agar dunia usaha dapat tumbuh serta berkembang secara sehat dan benar, sehingga tercipta iklim persaingan usaha yang sehat serta terhindarnya pemusatan kekuatan ekonomi pada perseorangan atau kelompok tertentu. Maka dalam penulisan ini persoalan yang dibahas adalah: Bagaimanakah bentukperjanjian yang dilarang dalam Undang-undang Nomor 5 Tahun 1999 Tentang Larangan Praktek Monopoli Dan Persaingan Usaha Tidak Sehat yang dilakukanolehpelakuKeramba Jaring Apung di HaranggaolHorisan Kabupaten Simalungun?

\section{Metade Penelitian}

Jenis penelitian yang digunakan adalah penelitian hukum normatif dengan melakukan pendekatan integrasi keilmuan antara perspektif ilmu hukum dengan berbagai teori hukum. Dimana dari sudut pandang teori hukum, ilmu hukum dibagi atas tiga lapisan utama, yaitu dagmatik hukum, teori hukum dan filsafat hukum. ${ }^{28}$ Pendekatan canseptual appraach dengan melakukan pendekatan integrasi keilmuan antara perspektif ilmu hukum dengan teori hukum digunakan dalam mengkaji permasalahan terkait. Pendekatan knnseptual beranjak dari pandangan-pandangan dan daktrin-daktrin yang berkembang di dalam ilmu hukum. Dengan mempelajari pandangan-pandangan dan doktrin-daktrin yang berkembang di dalam ilmu hukum, akan menemukan sesuatu

${ }^{28}$ Hadjon, P. M., \& Djatmiati, T. S, Argumentasi Hukum. 2005, (Yogyakarta: Gadjah Mada University Press) 
yang baru (samething new) berupa ide-ide yang melahirkan pengertian-pengertian hukum, kansep-knnsep hukum, dan asas-asas hukum yang relevan dengan isu yang dihadapi. ${ }^{29}$

\section{PEMBAHASAN}

Bentuk perjanjian yang dilarang dalam Undang-undang Nomor 5 Tahun 1999 tentang larangan praktek monopoli dan persaingan usaha tidak sehat yang dilakukan oleh pelaku keramba jaring apung di Haranggaol Horisaon Kabupaten Simalungun, yaitu:

I. Perjanjian Dligapali yang Dilakukan oleh Pelaku Usaha Keramba Jaring Apung di Haranggaol Horison.

Berbeda dengan pasar persaingan sempurna, dalam pasar oligopoli masing-masing pedagang mempunyai kekuatan untuk menentukan pasar. Dalam pasar jenis ini pedagang dapat saling bersaing atau dapat melakukan kolusi di antara mereka. Jika penjual saling bersaing, maka dampaknya akan mirip dengan apa yang terjadi pada pasar persaingan sempurna. Biasanya penjual akan berlamba memberikan yang terbaik bagi konsumennya dengan tingkat harga tertentu. Berdasarkan infarmasi yang diperoleh bahwa Pelaku usaha yang melakukan Dligopoli ya tauke-tauke ikan itu lah,karena disini ada istilah "siapa yang kuat,dia yang menang. Maksudnya seperti ini, tauke-tauke ikan ini kebanyaan adalah arang berada dan banyak uang. Kolam keramba jaring apung mereka juga banyak. Tapi mereka juga menampung ikan dari petani kecil seperti sayalah ya contohnya. Saya juga berkeramba nya di Haranggaol. Jadi tauke-tauke ikan ini suka hatinya kadang nentukan harga waktu nampung ikan dari petani kecil ini. Alasan yang paling sering dibilang orangitu banjir ikan di pasar,jadi harga ikan turun,itu lah sering alasan orangitu. Padahal tidak ada banjir ikan,ya itu lah karna kan petani ikan kecil kek kami ini ga tau mau menjual kemana lagi,kalau kami yang langsung distribusikan,mati di madal kami,terus belum tentu pasar juga mau nerima ikan dari kami karna ikan orang itu kebanyakan dari tauke-tauke

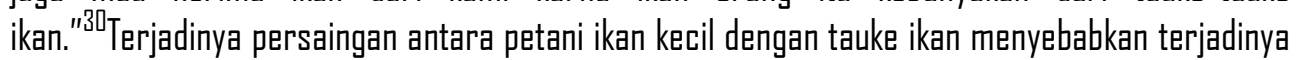
pasar Cligopali di Haranggaol Horison. Tauke memiliki kekuatan untuk menentukan gerak pasar,baik dari segi kuantitas produk, bahkan harga. Tauke menawarkan harga yang lebih murah kepada para penampung ikan (pedagang pasar) dibanding petani kecil. Karena kuantitas yang memenuhi pasar dan harga yang ditawarkan lebih murah, tentu pedagang lebih memilih untuk membeli produk dari tauke ikan dibanding dari petani kecil. Sehingga petani kecil mau tidak mau menurunkan harga mengikuti harga yang ditetapkan oleh tauke ikan. Tauke ikan membentuk pasar Oligapali di Haranggaol Horison.

2. Perjanjian Penetapan Harga (Price Fixing Agreement) yang Dilakukan oleh Pelaku Usaha Keramba Jaring Apung di Haranggaol Horison

Pada pasar yang bersifat Dligopolis ataupun pasar yang dikuasai oleh pelaku usaha yang memiliki posisi dominan penentuan harga dapat dilakukan hanya dengan memberikan tanda kepada pelaku usaha lainnya dengan bentuk menaikkan/menurunkan harga yang biasanya akan selalu diikuti oleh pelaku usaha lainnya (tacit collution). Informasi yang diperoleh dari pedagang pasar, efek perjanjian penetapan harga menguntungkan pelaku usaha pedagang, yakni: "Pedagang ikan senang-senangnya aja пуa. Istilahnya senang sama senanglah. Siapa yang menawarkan harga paling murah itulah kami tampung.karna kami kan pedagang pasar ini juga tidak mau rugi,saalnya ikannya kan mau kami jual lagi. Makanya kadang kami lihat-lihat dulu mana tauke yang nawar

\footnotetext{
${ }^{29}$ Marzuki, P. M, Penulisan Hukum. 2005, (Jakarta: Kencana Prenada Media Group)

${ }^{30}$ Wawancara dengan Bapak Rikson Saragih selaku Petanilkan Kecil di Haranggaol Horizon padaTanggal IG April 2020
} 
harga murah,langsung kami tampung." ${ }^{31}$ Berdasarkan hasil penelitian tentang perjanjian penetapan harga terjadi Haranggaol Horison, bahwa Pihak yang melakukan perjanjian adalah pelaku usaha yang saling bersaing dalam hal ini sesama tauke. Para pelaku usaha menyepakati harga ikan pada nominal tertentu untuk diberikan kepada pedagang. Karena harga yang lebih murah daripada yang lain, maka pedagang lebih memilih tauke yang menawarkan harga yang lebih murah. Karenanya para pihak yang tidak turut melakukan perjanjian dalam hal ini petani ikan kecil tidak mempunyai pilihan lain, apakah menaikkan atau menurunkan harga.

3. Perjanjian Dligapsani yang Dilakukan oleh Pelaku Usaha Keramba Jaring Apung di Haranggad Horison

Oligopsoni adalah struktur pasar yang di dominasi oleh sejumlah konsumen yang memiliki kontrol atas pembelian. Struktur pasar ini memiliki kesamaan dengan struktur pasar oligapoli hanya saja struktur pasar ini terpusat di pasar input.Tidak adanya pilihan lain bagi pelaku usaha untuk menjual produk mereka selain kepada pelaku usaha yang melakukan praktek oligapsani, mengakibatkan mereka hanya dapat menerima saja harga yang sudah ditentukan oleh pelaku usaha yang melakukan praktek oligopsoni.Sebagaimana hasil wawancara dengan pedagang pasar yang dalam kasus ini memiliki posisi sebagai pembeli, bapak tersebut menyatakan bahwa kalau biasanya disini memang kerap terjadi yang namanya saling menjatuhkan. Biasanya itu terjadi antar tauke ikan dan pesaingnya yang lain, mereka biasanya saling menjatuhkan dengan berlumba-lumba menurunkan harga ikan pada saat mendistribusikannya ke kami pedagang pasar. Kadang dari tauke A menawar sama kami dengan harga Rp 22.000, tapi ada tauke lain yang mungkin lebih keras keuangannya kan, ditawar sama kami Rp 20.000. Ya kalau kami selaku pedagang pasar ya jelas lah lebih memilih harga yang lebih murah ya karna kan kami mau menjual lagi ke knnsumen, jadi kami nampung mana yang lebih murah aja." ${ }^{32}$ Terjadinya praktek oligopsoni di Haranggaol Horison terjadi karena produsen atau petani ikan kecil tidak memiliki alternatif lain untuk menjual produk mereka selain kepada pedagang yang telah melakukan perjanjian harga dengan tauke ikan. Tidak adanya pilihan lain bagi petani ikan kecil untuk menjual produk mereka selain kepada pedagang yang melakukan perjanjian harga dengan tauke ikan, mengakibatkan mereka hanya dapat menerima saja harga yang sudah ditentukan oleh tauke.

4. Perjanjian Integrasi Vertikal yang Dilakukan oleh Pelaku Usaha Keramba Jaring Apung di Haranggaol Integrasi vertical adalah segala praktik yang bertujuan untuk mencapai suatu kondisi yang membatasi persaingan dalam dimensi vertical atau dalam perbedaan jenjang produksi atau dalam usaha yang memiliki keterkaitan sebagai rangkaian produksi atau rangkaian usaha.Namun yang harus dipertegas dalam Integrasi Vertikal bahwa hambatan yang dilakukan para pelaku usaha adalah hambatan dalam proses produksi barang. Sebagaimana yang telah dikemukakan selaku petani kecil:Masalah yang sering dihadapi itu terutama mengenai kualitas bibit, kemudian kualitas pakan, dan paling krusial itu harga pasar yang tidak menentu. Contohnya kalau kualitas bibit itu dari pembibitan sana bercampur-campur, Kalau ada istilahnya disini yang monosek katanya yang unggul tapi itu dicampur sama petani bibit disana, istilahnya disini bibit bondar (bibit kualitas c). Jadi kalau dibudidayakan itu, tidak merata besaarnya.kemudian masalah kualitas pakan ikan ini. Kalau diliat di label nya itu kandungan protein 30\%, tapi hasilnya di lapangan belum tentu seperti itu, melihat hasil panennya tidak sesuai dengan pakan yang telah diberikan.Kemudian karena tauke-tauke di Haranggaol ini mereka juga memasak pakan ikan. Kalau mereka bermitra dengan petani, jelas mereka juga mengambil untung dari pakan nya juga.Dari

\footnotetext{
${ }^{31}$ Wawancara dengan Pedagang Pasar, Bapak Fresh Lingga di Haranggaol Horizon Tanggal 23 April 2020

${ }^{32}$ lbid
}

Tinjauan Yuridis Terhadap Perjanjian Yang Dilarang dalam Undang-Undang Nomor 5 Tahun 1999 T

Entang Larangan Praktek Monopoli Dan Persaingan Usaha Tidak Sehat yang Dilakukan Dleh Pelaku 


\section{Simpulan}

tauke bibitnya, dari dia pakan nya, produksinya pun dia yang mengambil. Kalau tauke-tauke itu tetap untung, kalau petani kecil sangat-sangat mengkhawatirkan untuk situasi sekarang ini." ${ }^{33}$ Integrasi antar pelaku usaha di Haranggaol Horison dilakukan untuk saling menutupi kelemahan dari masing masing pelaku usaha (dalam hal ini tauke) yang melakukan integrasi, karena sudah pasti setiap tauke memiliki kelemahan-kelemahan tersendiri, misalkan satu tauke memiliki kelemahan dalam kualitas bibit ikan, tetapi unggul dalam kuantitas produksi dapat bergabung dengan tauke lain yang mungkin memiliki kelebihan dalam pengelolaan kualitas bibit ikan tetapi kurang dalam kuantitas produksi, dimana kemudian diharapkan dengan terjadinya integrasi kelemahan-kelemahan yang ada dapat ditutupi atau bahkan dihilangkan.

Berdasarkan pembahasan di atas, dapat ditarik simpulan, sebagai berikut:

1. Bentuk perjanjian yang dilarang berdasarkan Undang-Undang 5 Tahun 1999 yang dilakukan pelaku usaha di Haranggad Horison adalah:

a. Cligopoli adalah keadaan pasar yang produsen penjual barang hanya sedikit sehingga mereka atau searang dari mereka dapat mengaruhi harga.

b. Perjanjian Penetapan Harga (Price Fixing Agreement) adalah kondisi dimana produsen menetapkan harga yang harus dibayar pembali untuk barang dan/atau jasa yang diperdagangkan di pasar bersangkutan yang sama dari segi faktual dan gegarafis. Perjanjian harga akan menjadikan harga menjadi tinggi, bukan harga pasar.

c. Cligapsoni adalah struktur pasar yang di dominasi oleh sejumlah konsumen yang memiliki kontrol atas pembelian. Struktur pasar ini memiliki kesamaan dengan struktur pasar oligopoli hanya saja struktur pasar ini terpusat di pasar input. Dengan demikian distarsi yang ditimbulkan oleh kolusi antar pelaku pasar akan mendistorsi pasar input.

d. Integrasi vertikal adalah segala praktik yang bertujuan untuk mencapai suatu kondisi yang membatasi persaingan dalam dimensi vertikal atau dalam perbedaan jenjang produksi atau dalam usaha yang memiliki keterkaitan sebagai rangkaian produksi atau rangkaian usaha.

2. Bahwa terjadi banyak perjanjian yang dilarang dalam Undang-Undang Nomar 5 Tahun 1999 yang dilakukan oleh pelaku usaha kerambaga jarring apung di Haranggaol Horison. Perjanjian-perjanjian yang dilarang yang dilakukan oleh pelaku usaha ikan antara lain: Dligopoli, Perjanjian Penetapan Harga, Perjanjian Dligapsani, dan Perjanjian Integrasi Vertikal. DibuatnyaPPNomor72Tahun2OI6 yang kini biasa disebut sebagai PP holding ini karena peraturan pemerintah yang sebelumnya yaitu PP Nomor 44 Tahun 2005 tentang Tata Cara Penyertaan dan Penatausahaan Modal Negara Pada Badan Usaha Milik Negara dan Perseraan terbatas dinilai tidak cukup mengatur tentang inisiasipembentukan holding sektoral dilndanesia. Melaluii PP Nomor 72 Tahun 2016 ini kita dapat mengetahui bahwa setelah di lakukannya restrukturisasi, anak perusahaan dari holding BUMN statusnya tidak lagi menjadi BUMN sebagaimana yang terjadi pada PT Perusahaan Gas Negara Tbk.

\section{DAFTAR PUSTAKA}

\section{Buku}

Hadjon, P. M., a Djatmiati, T. S. 2005, Argumentasi Hukum. Yogyakarta:Gadjah Mada University Press Indiraharti, Novina Sri. 2002, Aspek Keabsahan Perjanjian dalam Hukum Kantrak. Bandung: Intermasa Karwapi. I985, Perikanan di Indanesia. Jakarta: Jakarta Press Marzuki, P. M. 2005, Penulisan Hukum. Jakarta: Kencana Prenada Media Group

\section{${ }^{33}$ Dp.Cit, Wawancara dengan Bapak Rikson Saragih}


Muhammad, Abdulkadir. 2002, Hukum Persaingan Usaha. Bandung: Citra Adyta Bakti

Muhammad, Abdul Kadir. 19988. Hukum Perjanjian. Bandung: Alumni

Nugraho, Susanti Adi. 200I, Pengaturan Hukum Persaingan Usaha di Indanesia. Jakarta: Puslitbang/Diklat Mahkamah Agung.

Rakan, Mustafa Kamal. 20ID, Hukum Persaingan Usaha. Jakarta: PT Raja Grafinda Persada

Subekti. 1996, Hukum Perjanjian. Cetakan XVI. Jakarta: Intermasa

Jurnal

Chatamarrasjid. 1999, Akumulasi ketentuan Uل No. $5 / 19999$ tentang Larangan Praktik Manapoli (Magna Charta bagi Kebebasan berusaha)". Jurnal Hukum Bisnis, Vol. 7.Jakarta: Yayasan Pengembangan Hukum Bisnis.

R.B. Suhartono. 1998, Kang/amerasi dan Relavansi Uل Antitrust/ Uل Antimanapali di Indanesia. Jurnal Hukum Bisnis, Volume 4

\section{Skripsi}

Rismawati. 2010, Analisis Daya Dukung Perairan Danau Taba Terhadap Kegiatan Perikanan Sebagai Dasar Dalam Pengendalian Pencemaran Keramba daring Apung. (Skripsi Sarjana Universitas Sumatera Utara, Fakultas IImu Sosial dan Politik, 20I0)

\section{Peraturan Perundang-undangan}

Uل Nomar 5 Tahun 1999 tentang Larangan Praktek Manapali dan Persaingan Usaha tidak Sehat.

Konsiderans Undang-Undang Nomor 5 Tahun 1999 tentang Larangan Praktik Monopali dan Persaingan Usaha Tidak Sehat.

Tim Panitia Antar Departemen Jakarta 2010 Rancangan Undang-Undang tentang Dtaritas Jasa Keuangan Naskah Akademik Pembentukan DJK.

Tim Panitia Antar Departemen Rancangan Undang-Undang Tentang Dtaritas Jasa Keuangan Jakarta. 20ID.

Kamus Naskah Akademik Pembentukan Dtaritas Jasa Keuangan (DJK).

Henгy Campbell Black, Black Law Dictionary, (St Paul West Publishing Co). 1999.

Kamus Besar Bahasa Indanesia Letakan Ke IV

Internet

https://www.jurnal.id/id/blog/pendekatan-dan-prinsip-etika-bisnis-perusahaan/

http://www.sindikat.co.id 